\title{
Religion and Film: Cinema and the Re-Creation of the World, by S. Brent Plate
}

Short Cuts | London: Wallflower Press [now Columbia University Press], 2009|x + I I 2 pages | ISBN: 978-I-905674-69-5 (softback) $\$ 22.00$

With Religion and Film: Cinema and the Re-Creation of the World, Brent Plate breaks new ground in the field of religion and film studies, and makes an invaluable contribution to the study of religion's reception. In this monograph, Plate utilizes analogy to argue that religion and film are like one another, and that they construct their narratives in similar ways. He employs anthropologist Clifford Geertz's definition of religion, and although the definition is contested in other contexts for its emphasis on meaning-making, for the specific purposes of Plate's comparative analysis such a definition is a valuable tool. For film, Plate samples from across the stylistic continuum of cinema-Hollywood blockbusters, independents, international "art house" and experimental film-demonstrating the broad application of his thesis. This book complements John C. Lyden's Film as Religion: Myths, Morals, and Rituals (2003) which makes the case for film itself as a religious practice. While both Plate and Lyden engage with myth in cinematic narrative and the ritual of filmgoing itself, Plate moves beyond Lyden's foundational work. Through the analysis of the formal elements of film-cinematography, editing, sound, and mise-en-scéne (what is in front of the camera, i.e., props, setting, characters, costumes, lighting)—he argues for the similarities in the construction of religious and cinematic narratives.

With a preface, introduction, and four chapters, this monograph runs only I I 2 pages so Plate's work is not a comprehensive study; instead it serves as a catalyst for further analysis. Each chapter can be considered a launch point for a classroom discussion as it establishes the theoretical framework in an accessible manner, applies it cogently to case studies, and inspires additional investigation.

Drawing from film theorists like Sergei Eisenstein and religion theorists like Wendy Doniger, Plate argues that religion and film are like one another as they share in how they draw from the same cultural well, and construct narratives with similar purpose. As sociologist of religion Peter Berger argues in The Sacred Canopy (1967), humans create ordered worlds that provide 
a sense of stability, security, and meaning. Both religion and film engage in this process of "worldmaking." They both "function by recreating the known world and then presenting that alternate version of the world to their viewers/worshippers" (2).

Drawing on Berger, Goodman and Paden, Plate compares the worldmaking of religion to that of film. For both religion and film, their alternative worlds can inspire and caution, and offer "prescriptions for a better life and imaginative tools for reviewing the world as it is" (2). Religion frames and focuses its narrative through myths, rituals, and symbols. Film uses formal elements like cinematography, editing, set and costume design to achieve similar results.

An important strength of the book is that Plate acknowledges that worldmaking carries ideological implications. So with each chapter, he indicates how narratives can reinforce oppressive social structures. For example, embedded in the mythic narrative of The Matrix (1999) is Hollywood's reinscribing of heterosexual attractive white male supremacy with Neo (Keanu Reeves) as savior.

As Plate demonstrates the similarity between religion and film in each chapter, he also argues how, given that similarity, the study of cinematic construction can shed light on religion and vice-versa. In chapter I, "Visual Mythologizing," Plate acknowledges the prior studies done on the power of myth in film. However, while these studies focus on narrative tropes, like the Hero's Journey, Religion and Film goes further to demonstrate how myth is communicated in non-narrative and non-verbal ways. Plate uncovers how cinematography and mise-en-scéne communicate the myth. The visual experience of film reminds us that myth is not only a cerebral exercise but also one to be experienced through the senses, just as religion communicates in non-verbal ways like the ordered tranquility of the Japanese Zen garden.

For the film student, understanding the power of myth and how it shapes lives will give them greater insight into the cinematic narrative like the mythic world of Star Wars that opens by visually establishing "a galaxy far, far away" threatened by chaos. At the same time, the student of religion encounters the pastiche of The Matrix (1999) with its blend of Christian, Buddhist, and postmodern symbols informing its world, and can come to a better understanding of how Christianity has practiced syncretism from its inception. For example, the Jewish Passover transforms into Holy Communion.

In chapter 2, "Ritualizing Film in Space and Time," Plate affirms the importance of ritual via anthropologist Bobby Alexander's understanding of 
the practice as a performance that "opens up ordinary life to ultimate reality ... to tap its power" (40). Given the vital nature of ritual, Plate turns to critically acclaimed independent films to examine how film employs ritual and what aesthetic impulses lie behind the practice. Plate connects ritual to film through an analysis of the use of movement through space and time.

Spatial relations are integral to religious ritual—the Jewish synagogue oriented toward Jerusalem, or the Muslim facing toward Mecca five times a day. In film, the placement of the camera establishes spatial relationships between objects. Shots and scenes then reveal "metonymically something about the larger narratives of the films" (39). Blue Velvet (1986) brings the viewer into a cosmos where the vertical camera movement establishes an apparent idyllic world from the blue sky and white picket fence to the chaos that lives below ground. In Antonia's Line (1995) the verticality represents the male hierarchy of the church and horizontal lines create an egalitarian community facilitated by women. For the students of religion and film, examining how ritual movement functions in either vertically or horizontally, in either a hierarchical or an egalitarian manner, reveals that "spatial dimensions can often be ideologically charged" in their display of gender roles and other identities (57).

Plate closes this chapter with a look at the power of editing in Vertov's Man with a Movie Camera (1929) and Ron Fricke's Baraka (1992). In these films, the collapsing of space and time allows for a unique perspective that uncovers the sacredness of the ordinary and the interconnectedness of all things.

Chapter 3, "Religious Cinematics," may be Plate's most ambitious and at the same time the least accessible, given that his primary case studies are with experimental film, a genre little viewed, and for many an acquired taste. He turns to these films because more often than not they represent reality as other, challenging the viewer to a new understanding, similar to how religious ritual re-creates the world. Plate's focus here shifts to the sensual reception of the embodied viewer. He makes two important comparisons. First, how the audience member's physical reaction to the ritualized aspects of film is similar to that of the participant in a religious ritual. While rituals act upon bodies through speech, music, and performance, they are also acted out by bodies. For the film viewer, cinema stirs the body whether reacting to fear or sadness, happiness or humor.

Second, Plate compares the epistemological experience of the worshipper to the filmgoer. Shifting away from Cartesian objectivity, he appeals to 
Merleau-Ponty and a knowing that is rooted in feeling, and therefore open to doubt. For film theorist Christian Metz, film viewers are aware that the film is fictional, yet, even as they suspend their disbelief, a part of them believes in the truth of the story. Plate finds an analogous phenomenon in the religious worshipper who may not believe in the ancient stories of the sacred texts but still has a sense of their truth, and then physically reacts to that truth through the ritual.

With experimental film, Plate finds a cinematic experience that can shatter an audience's preconceptions, making way for a mystical experience that is religious. In The Act of Seeing With One's Own Eyes (1971), Stan Brakhage's camera literally records the peeling back of the layers of a real human corpse (not a Hollywood fabrication). This disconcerting crossing of boundaries between life and death, the pure and impure, enables the viewer to transgress social norms, seeing the world differently. Ultimately, Plate's claim that experimental film offers an alternative to Hollywood's hegemony that allows for the possibility of "aesthetic, ethical and religious renewal" may be accurate but is an alternative that many of us may not choose to pursue (69). However, his basic premise that film can physically move us in ways that break down barriers, and allow new insights, need not be constrained to the experimental.

In the final chapter, "The Footprints of Film," Plate draws attention to the new ways in which media transmits religion. Film merges into religion and vice versa as television, and video games inform audiences about ideas of good and evil. Meanwhile, evangelicals use film and video directly in their services, and more mainstream churches utilize film in their religious education. As media alters ritual, it raises the question: do religious rituals need rethinking? "Filmed characters and scenarios have come down off the screen" and entered the contemporary religious landscape (79). Theme weddings and Bar Mitzvahs draw on motifs from hit television series and blockbuster films with participants dressing up as characters from Star Trek (1966-1969), The Matrix (1999), and Gone with the Wind (1939). Teen spirituality and identity today are informed by popular shows and movies like Buffy the Vampire Slayer (1997-2003) and the Harry Potter franchise. A new generation finds spiritual expression in the ritual attendance of the cult classic The Rocky Horror Picture Show (1975) and the philosophy of Star Wars has inspired a Jedi religious movement. This final chapter acts as a clarion call for further research. What does this blurring of religion and media mean for the future of both, and the ongoing transmission of religious values? 
Throughout the book Plate demonstrates an impressive knowledge of both film and religious studies, making his insights into the intimate dialogue between religion and cinema quite compelling. His style is engaging and accessible, suitable for undergraduates and graduates. Both students of religion and film will find this monograph a persuasive engagement with their disciplines. Religion and Film is an excellent addition to Wallflower's Short Cuts series of introductions to film studies.

Daniel S. Cutrara

Arizona State University 